\title{
PENGARUH REKRUTMEN, SELEKSI, DAN PENGEMBANGAN KARIR TERHADAP PRESTASI KERJA KARYAWAN
}

\author{
Ni Made Mely Cahyani ${ }^{1}$ \\ I Wayan Mudiartha Utama ${ }^{2}$
}

${ }^{1,2}$ Fakultas Ekonomi dan Bisnis Universitas Udayana (Unud), Bali, Indonesia E-mail: cmelly96@gmail.com

\begin{abstract}
ABSTRAK
Tujuan penelitian ini adalah untuk menganalisis pengaruh rekrutmen, seleksi, dan pengembangan karir terhadap prestasi kerja karyawan. Populasi penelitian ini adalah seluruh pegawai tetap pada PT Tunas Jaya Sanur yang berjumlah 160 orang. Teknik sampling yang digunakan adalah proportional random sampling dengan pendekatan slovin sebagai metode penentuan sampel, sehingga sampel yang digunakan sebanyak 61 orang. Data di analisis menggunakan teknik analisis regresi linier berganda. Hasil analisis data menunjukkan bahwa rekrutmen, seleksi, dan pengembangan karir berpengaruh positif secara simultan ataupun parsial terhadap prestasi kerja karyawan. Hal ini dapat disimpulkan bahwa semakin baik rekrutmen, semakin baik seleksi serta semakin kuat pengembangan karir pada PT Tunas Jaya Sanur maka akan semakin tinggi prestasi kerja karyawan. Nilai determinasi total (R Square) sebesar 0,625 mempunyai arti bahwa sebesar $62,5 \%$ variasi prestasi kerja karyawan PT Tunas Jaya Sanur dipengaruhi oleh rekrutmen, seleksi, dan pengembangan karir, sedangkan sisanya sebesar $37,5 \%$ dipengaruhi oleh faktor lain diluar penelitian.
\end{abstract}

Kata Kunci: rekrutmen, seleksi, pengembangan karir, prestasi kerja karyawan

\begin{abstract}
The purpose of this study was to analyze the effect of recruitment, selection, and career development on employee performance. The population of this study was all permanent employees at PT Tunas Jaya Sanur, amounting to 160 people. The sampling technique used was proportional random sampling with the Slovin approach as a sample determination method, so that the sample used was 61 people. The data were analyzed using multiple linear regression analysis techniques. The results of data analysis show that career recruitment, selection and development have a positive or simultaneous effect on employee performance. It can be concluded that the better the recruitment, the better the selection and the stronger the career development at PT Tunas Jaya Sanur, the higher employee performance will be. The total determination value ( $R$ Square) of 0.625 means that $62.5 \%$ of the variation in the work performance of PT Tunas Jaya Sanur employees is influenced by recruitment, selection, and career development, while the remaining $37.5 \%$ is influenced by other factors outside the research.

Keywords: recruitment, selection, career development, employee performance
\end{abstract}




\section{PENDAHULUAN}

Sumber daya manusia adalah harta atau aset yang paling berharga dan paling penting yang dimiliki oleh suatu organisasi atau perusahaan, karena keberhasilan organisasi sangat ditentukan oleh unsur manusia (Ardana dkk., 2012:6). Tanpa adanya sumber daya manusia dalam suatu perusahaan maka aktivitas perusahaan tidak akan berjalan (Hasibuan, 2008:12), maka dari itu pengelolaan SDM yang baik bukanlah merupakan suatu pilihan, namun suatu keharusan bagi organisasi jika ingin berkembang dan memiliki daya saing. Abdul (2014) menyatakan perusahaan sangat membutuhkan karyawan yang bersedia memberikan seluruh kemampuannya demi kepentingan perusahaan dan karyawan yang dapat bertanggung jawab untuk pekerjaan yang dilakukannya, sedangkan karyawan mengharapkan perusahaan dapat memberikan penghargaan dan pengakuan yang adil atas prestasi kerja mereka.

Prestasi kerja merupakan suatu hasil kerja yang dicapai seseorang dalam melakukan tugas-tugas yang diberikan kepadanya yang berdasarkan kecakapan, pengalaman, dan kesungguhan serta ketepatan waktu (Akmal, 2015). Penilaian prestasi kerja merupakan kegiatan untuk membantu perusahaan meningkatkan prestasi kerja karyawan. Bagi perusahaan penilaian prestasi kerja karyawan dapat memotivasi pegawai untuk meningkatkan prestasi kerjanya, yang akan memberikan dampak positif bagi perusahaan itu sendiri (Cahyono dan Adnyani, 2014).

Menurut Heikal (2016) prestasi kerja karyawan yang baik, didukung dengan adanya penarikan karyawan (rekrutmen) yang baik dan sesuai. Penarikan 
karyawan atau rekrutmen merupakan serangkaian kegiatan yang dimulai ketika sebuah perusahaan memerlukan tenaga kerja dan membuka lowongan sampai mendapatkan calon karyawan yang diinginkan sesuai dengan jabatan atau lowongan yang ada (Oaya et al., 2017). Penarikan karyawan ini merupakan proses menentukan atau menarik pelamar yang mampu untuk bekerja dalam suatu perusahaan sesuai dengan kemampuan yang dimilikinya (Rofiatun, dkk., 2017).

Penelitian yang dilakukan oleh Rofaita (2012) menyatakan bahwa rekrutmen karyawan memiliki hubungan positif terhadap prestasi kerja karyawan, karena semakin bagus rekrutmen yang dilakukan oleh perusahaan maka akan semakin meningkatkan prestasi kerja karyawan. Penelitian serupa oleh Afriyie et al. (2013), Zulianti (2014), Ekowoaba et al. (2015), Lukiyana dan Sriyanto (2017) menemukan hasil bahwa rekrutmen mempunyai pengaruh yang positif signifikan terhadap prestasi kerja. Hal ini berarti bahwa semakin selektif perusahaan untuk merekrut tenaga kerja, maka prestasi kerja yang dihasilkan karyawan tersebut akan semakin meningkat.

Menurut Zulianti (2014) prestasi kerja karyawan juga dipengaruhi oleh seleksi karyawan yang dilakukan oleh perusahaan. Seleksi tenaga kerja diartikan sebagai suatu proses pemilihan beberapa orang dari sekelompok orang-orang dengan preferensi tertentu menurut (Wahyuni dan Ruhana 2014). Seleksi tenaga kerja adalah kegiatan untuk menentukan dan memilih tenaga kerja yang memenuhi kriteria yang telah ditetapkan perusahaan serta memprediksi kemungkinan keberhasilan/kegagalan individu dalam pekerjaan yang akan diberikan kepadanya (Masud, 2015). Tujuan adanya seleksi adalah untuk 
mendapatkan tenaga kerja yang tepat untuk memangku suatu jabatan tertentu (Kiruja, 2013).

Penelitian Zulianti (2014) menyatakan bahwa seleksi berpengaruh positif terhadap prestasi kerja karyawan. Rofaita (2012) dalam penelitiannya menyatakan bahwa semakin baik penerapan seleksi karyawan maka prestasi kerja karyawan akan meningkat. Hasil penelitan serupa oleh Omolo et al. (2012), Afriyie et al. (2013), Ekowoaba et al. (2015) dan Sarinah (2016) juga menyatakan bahwa seleksi berpengaruh positif dan signifikan terhadap prestasi kerja karyawan. Hal ini berarti bahwa semakin tepat proses seleksi yang dilakukan, maka perusahaan akan memperoleh karyawan yang berkompeten, sehingga akan mampu mencapai prestasi kerja yang tinggi.

Chukwudi (2014) mengemukakan untuk menunjang pencapaian prestasi kerja tersebut perusahaan harus melakukan rekrutmen atau penarikan karyawan dengan melakukan penyeleksian terlebih dahulu guna mendapatkan calon karyawan yang berkompeten. Proses penerimaan karyawan baru harus dilakukan sesuai dengan prosedur yang ditetapkan perusahaan yang mana penerimaan disesuaikan dengan kebutuhan perusahaan (Irfan, 2012). Perusahaan yang sudah melakukan proses rekrutmen dan seleksi dengan tepat tentu akan mendapat karyawan yang berkompeten dengan prestasi kerja yang tinggi.

Selain rekrutmen dan seleksi karyawan, terdapat faktor lain di dalam perusahaan yang sangat penting yaitu pengembangan karir. Karyawan dapat mengembangkan karirnya dengan baik, maka hal tersebut dapat meningkatkan prestasi kerja karyawan (Sunday et al., 2015). Menurut Taghulihi (2015) dan 
Heikal (2016) pengembangan karir merupakan urutan aktivitas-aktivitas yang berhubungan dengan pekerjaan dan perilaku, nilai-nilai, dan aspirasi seseorang. Seorang karyawan yang ingin mengembangkan karirnya perlu memikirkan penilaian kinerja apa yang dimiliki (Sari dan Sinulingga 2011:80).

Menurut Charles (2014) pengembangan karir merupakan aspek penting yang tidak boleh dilupakan dalam mengelola sumber daya manusia. Seorang karyawan yang ingin mengembangkan karirnya perlu memikirkan penilaian kinerja apa yang dia miliki. Hasil penelitian Wahyuni dkk. (2014) menyatakan bahwa ada pengaruh positif dan signifikan antara pengembangan karir terhadap prestasi kerja karyawan. Penelitian serupa oleh Caroline et al. (2014), Kwenin (2014), Puspitasari dkk. (2015), Kawulusan dkk. (2016) dan Basuki (2017) menyatakan bahwa pengembangan karir berpengaruh positif dan signifikan terhadap prestasi kerja karyawan. Hal ini menunjukkan prestasi yang tinggi dapat ditentukan dari karir yang dimiliki oleh karyawan tersebut.

Penelitian ini dilakukan pada PT. Tunas Jaya Sanur, karena ditemkan adanya beberapa masalah terkait dengan prestasi kerja karyawan. Hasil wawancara dengan 20 orang karyawan menunjukkan bahwa terdapat 9 orang karyawan mengeluhkan masalah pekerjaannya ketika mereka di hadapkan pada pekerjaannya, dan sebanyak 11 orang karyawan merasa tidak nyaman atau kurang mengerti dalam mengerjakan pekerjaaan tersebut. Jika hal tersebut dibiarkan, karyawan masih tetap tidak mengerti dalam mengerjakan pekerjaan yang diamanahkan kepadanya, maka pekerjaan tersebut tidak akan dapat diselesaikan tepat waktu dan kelancaran perusahaan dapat terganggu. Permasalahan lain yang 
ditemukan pada PT. Tunas Jaya Sanur adalah masalah kondisi karyawan yang tidak tertarik atau mungkin malas untuk mengikuti kegiatan yang diadakan oleh perusahaan, sehingga seringkali karyawan datang terlambat ataupun menghindar untuk mengikuti kegiatan perusahaan dengan pulang lebih awal.

Berdasarkan hasil pra survey dengan HRD PT. Tunas Jaya Sanur juga ditemukan bahwa prestasi kerja karyawan PT. Tunas Jaya Sanur belum optimal dan maksimal dalam mengerjakan pekerjaannya. Hal ini ditunjukkan dengan banyaknya karyawan yang belum mampu mencapai prestasi kerja karyawan. Gambar 1 berikut menunjukkan tingkat pencapaian prestasi kerja karyawan PT. Tunas Jaya Sanur.

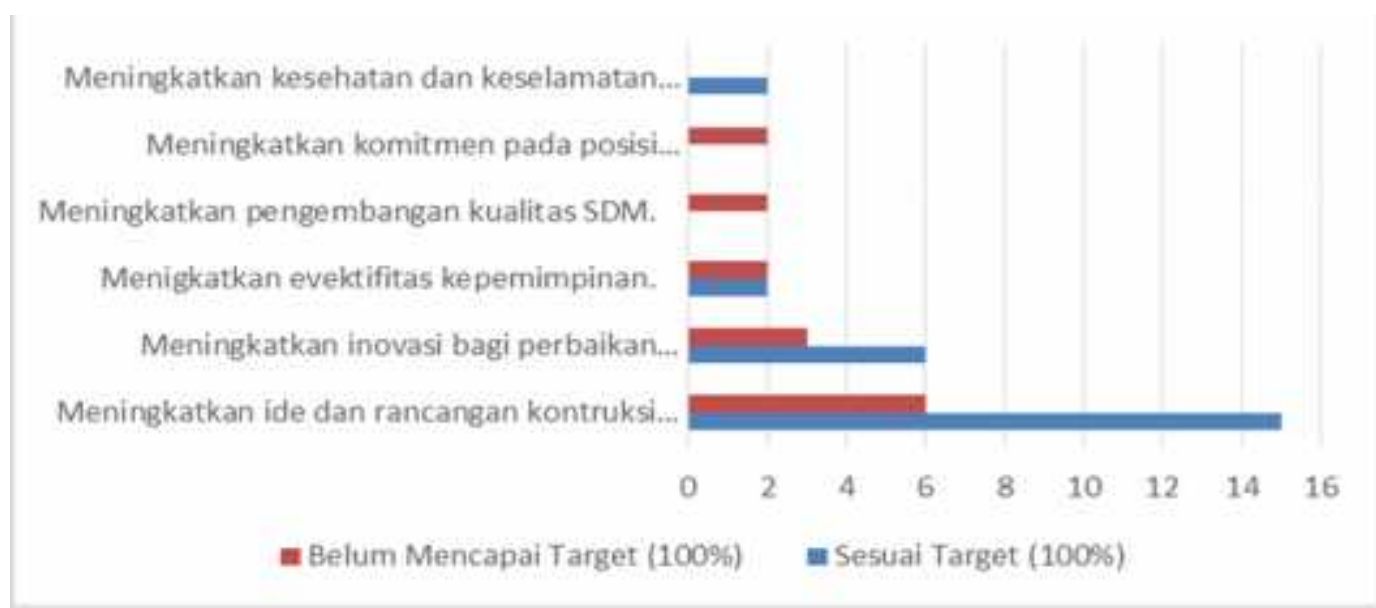

\section{Gambar 1. Tingkat Pencapaian Prestasi Kerja Karyawan}

Sumber : PT. Tunas Jaya Sanur, 2017

Gambar 2 menunjukkan bahwa prestasi kerja karyawan di PT. Tunas Jaya Sanur masih belum optimal, karena 5 indikator pengukuran yang digunakan masih belum mencapai target $100 \%$. Jumlah persentase sasaran yang belum mencapai target $100 \%$ bisa dikatakan cukup besar dan hal tersebut menggambarkan bahwa prestasi kerja karyawan masih rendah. 
Selain masalah mengenai rendahnya prestasi kerja karyawan, hasil pra survey juga menunjukkan bahwa rekrutmen karyawan pada PT. Tunas Jaya Sanur belum dilaksanakan secara maksimal, belum maksimalnya penarikan karyawan di perusahaan ini disebabkan karena kurangnya informasi dalam pempublikasian iklan lowongan kerja. Hal ini dikarenakan perlunya dana yang tidak sedikit baik dengan menggunakan media cetak atau media elektronik. Kondisi tersebut menyebabkan calon pelamar yang tidak mengetahui informasi lowongan pekerjaan ini sehingga calon karyawan yang mendapatkan informasi lowongan pekerjaan tersebut belum sesuai dengan kriteria perusahaan. Kebanyakan kandidat kurang memiliki pengalaman dan banyak juga jurusannya tidak sesuai dengan ekspetasi perusahaan. Hal ini disebabkan karena sudah terlanjur melakukan pempublikasian iklan lowongan pekerjaan, sehingga proses rekrutmen calon karyawan ini tetap dilaksanakan perusahaan dan akibatnya secara terpaksa harus menentukan pilihan dari sejumlah kandidat yang tidak ideal. Apabila PT. Tunas Jaya Sanur melakukan publikasi ulang, tidak sedikit biaya yang akan dikeluarkan lagi. Maka dari itu, kandidat yang sudah melamar walaupun tidak sesuai harapan perusahaan, tetapi akan dipilih dengat ketat juga dan akan dipilih yang paling terbaik. Hal tersebut menunjukan bahwa sistem rekrutmen karyawan pada PT. Tunas Jaya Sanur belum sepenuhnya menunjukan rekrutmen yang baik yang akan mengahsilkan karyawan yang berprestasi.

Seleksi karyawan yang dilakukan oleh PT. Tunas Jaya Sanur yang tidak sesuai dengan kriteria perusahaan ini dikarenakan dari rangkaian yang pertama dalam pengrekrutan calon tenaga kerja tidak banyak yang sesuai harapan 
perusahaan. Pada saat proses seleksi para HRD mengalami kesulitan untuk menentukan standar yang akan digunakan untuk mengukur kualifikasi-kualifikasi seleksi secara objektif, misalnya seperti, kejujuran, kesetiaan. Pewawancara seringkali mendapatkan jawaban tidak jujur dari pelamar, karena mareka selalu berusaha memberikan jawaban mengenai hal-hal yang baik-baik saja tentang dirinya, sedangkan yang hal yang negatif disembunyikan. Hal ini terungkap setelah kandidat lolos bekerja di perusahaan ini, para atasan pun akan mengetahui bagaimana sikap, sifat, dan pengetahuan karyawan tersebut. Hal ini dapat diketahui bahwa seleksi karyawan belum dilaksanakan secara maksimal bagi perusahaan untuk mendapatkan karyawan yang berprestasi.

PT. Tunas Jaya Sanur juga mengalami beberapa permasalahan yang berkaitan dengan pengembangan karir karyawan. Cara-cara perusahaan dalam usaha untuk pengembangan karir karyawannya adalah mengikuti pelatihan eksternal dan internal. Pelatihan internal itu, dilaksanakan di PT. Tunas Jaya ini sendiri meliputi untuk pelatihan Job Description, Standar Operasional Prosedur, dan Instruksi Kerja. Pelatihan eksternal itu mengikuti workshop yang diadakan di luar perusahaan. Dalam pengembangan karir ini, karyawan masih banyak yang tidak mengikuti pelatihan yang diadakan oleh perusahaan. Karyawan masih malas atau tidak tertarik untuk berpartisipasi dalam kegiatan tersebut. Padahal kegiatan tersebut untuk meningkatkan prestasi kerja karyawan. Atasan bisa memilih dan memilah mana karyawan yang akan dipromosikan jabatannya berdasarkan prestasi kerja karyawan tersebut. Hal ini harus diperhatikan perusahaan agar tidak 
berlarut-larut yang menyebabkan prestasi karyawan pada perusahaan ini belum optimal.

Berdasarkan latar belakang masalah yang telah dipaparkan dan kajian penelitian terdahulu tersebut di atas, maka tujuan penelitian ini adalah untuk mengetahui pengaruh rekrutmen, seleksi dan pengembangan karir karyawan terhadap prestasi kerja karyawan PT. Tunas Jaya Sanur. Berdasarkan tujuan penelitian tersebut, maka model penelitian ini dapat dilihat pada Gambar 2.

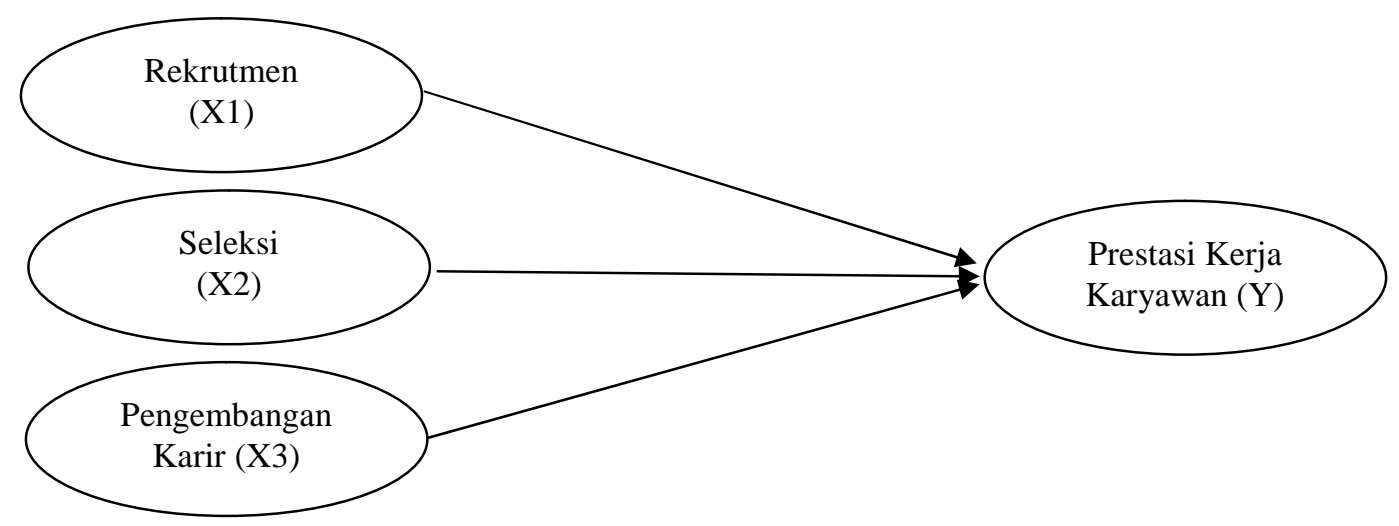

\section{Gambar 2. Kerangka Konseptual}

Sumber: Data diolah, 2018

Berdasarkan model penelitian pada Gambar 2 tersebut, maka dapat dibuat hipotesis sebagai berikut :

$\mathrm{H}_{1}$ : Rekrutmen karyawan berpengaruh positif terhadap Prestasi Kerja Karyawan.

$\mathrm{H}_{2}$ : Seleksi berpengaruh positif terhadap Prestasi Kerja Karyawan.

$\mathrm{H}_{3}$ : Pengembangan Karir berpengaruh positif terhadap Prestasi Kerja Karyawan.

\section{METODE PENELITIAN}

Penelitian ini dilakukan pada PT. Tunas Jaya Sanur yang berlokasi di Jl. By Pass Ngurah Rai No. 52XX, Sanur, Bali. Lokasi tersebut dipilih karena belum banyak yang melakukan penelitian di perusahaan tersebut mengenai sumber daya 
manusianya dan ingin mengetahui bagaimana prestasi kerja karyawan pada perusahaan ini. Obyek dalam penelitian ini yaitu prestasi kerja karyawan, rekrutmen, seleksi karyawan, dan pengembangan karir.

Berdasarkan pokok permasalahan dan hipotesis yang diajukan, variabel yang digunakan dalam analisis ini terdiri dari dua jenis variabel yaitu variabel independen dan dependen yang secara rinci dapat dilihat pada Tabel 1.

Tabel 1.

Rangkuman Variabel dan Indikator Penelitian

\begin{tabular}{|c|c|c|c|}
\hline No. & Variabel & Indikator & Referensi \\
\hline 1. & $\begin{array}{l}\text { Rekrutmen } \\
\text { Karyawan } \\
\text { (X1) }\end{array}$ & $\begin{array}{l}\text { 1) Balas Jasa } \\
\text { 2) Status Karyawan } \\
\text { 3) Persyaratan Jabatan } \\
\text { 4) Kesempatan mengembangkan karir } \\
\text { 5) Metode Penarikan }\end{array}$ & $\begin{array}{c}\text { Ardana,dk } \\
\text { k } \\
(2012: 58)\end{array}$ \\
\hline 2. & $\begin{array}{c}\text { Seleksi } \\
\text { Karyawan } \\
\text { (X2) }\end{array}$ & $\begin{array}{l}\text { 1) Keahlian } \\
\text { 2) Pengalaman } \\
\text { 3) Pendidikan } \\
\text { 4) Bakat } \\
\text { 5) Keadaan fisik }\end{array}$ & $\begin{array}{l}\text { Simamora } \\
(2004: 212)\end{array}$ \\
\hline 3. & $\begin{array}{c}\text { Pengembangan } \\
\text { Karir } \\
\text { (X3) }\end{array}$ & $\begin{array}{l}\text { 1) Perlakuan adil } \\
\text { 2) Kepedulian Atasan } \\
\text { 3) Kompetensi } \\
\text { 4) Informasi peluang promosi } \\
\text { 5) Minat untuk dipromosikan }\end{array}$ & $\begin{array}{l}\text { Siagian } \\
(2012)\end{array}$ \\
\hline 3. & $\begin{array}{l}\text { Akuntabilitas } \\
\text { Kinerja } \\
\text { (Y) }\end{array}$ & $\begin{array}{l}\text { 1) Hasil kerja } \\
\text { 2) Pengetahuan pekerjaan } \\
\text { 3) Inisiatif } \\
\text { 4) Kecekatan mental } \\
\text { 5) Sikap }\end{array}$ & $\begin{array}{l}\text { Dini dan } \\
\text { Agus } \\
(2014)\end{array}$ \\
\hline
\end{tabular}

Sumber: Kajian penelitian sebelumnya, 2018

Populasi dalam penelitian ini adalah seluruh karyawan tetap pada PT. Tunas Jaya Sanur yang berjumlah 160 orang. Pengambilan sampel dalam penelitian ini menggunakan Rumus Slovin. Berdasarkan perhitungan dengan rumus Slovin tersebut diperloleh jumlah sampel sebesar 61 orang, selanjutnya untuk pengambilan sampel menggunakan metode proposional random sampling, dimana sampel digolongkan menurut bagian dari pekerjaan, tidak termasuk pemimpin. 
Teknik analisis data yang digunakan dalam penelitian ini adalah analisis regresi linier berganda. Sebelum melakukan analisis regresi, penelitian ini melakukan uji instrumen penelitian dengan menggunakan uji validitas dan reliabilitas, serta melakukan uji asumsi klasik agar variabel yang dioperasikan memenuhi persyaratan sehingga tidak menimbulkan hasil yang bias dalam pengujian. Setelah data dinyatakan layak uji, maka dilakukan analisis regresi dengan persamaan model regresi linier beganda sebagai berikut :

$\mathrm{Y}=\alpha+\beta 1 \mathrm{X} 1+\beta 2 \mathrm{X} 2+\beta 3 \mathrm{X} 3+\mathrm{e}$

Keterangan :

$\mathrm{Y} \quad=$ Prestasi Kerja

$\alpha \quad=$ Konstanta

$\beta 1, \beta 2, \beta 3=$ Koefisien Regresi Variabel Independen

$\mathrm{X} 1=$ Rekrutmen karyawan

$\mathrm{X} 2=$ Seleksi karyawan

X3 = Pengembangan Karir

$\mathrm{e} \quad=$ Error / Variabel lain yang tidak teridentifikasi dalam model

\section{HASIL PENELITIAN DAN PEMBAHASAN}

Data penelitian diperoleh dari hasil kuesioner yang telah disebarkan kepada responden penelitian sejumlah 61 orang responden. Berdasarkan data dari 61 responden di PT Tunas Jaya Sanur karakterstik responden dilihat dari beberapa kriteria, yaitu jenis kelamin, usia, jabatan dan masa kerja. Karakteristik responden diuraikan dalam Tabel 2.

Berdasarkan data karakteristik responden yang ada pada Tabel 2 terlihat bahwa untuk klasifikasi jenis kelamin responden cenderung didominasi oleh lakilaki yakni sebesar 57,4 persen bila dibandingkan dengan persentase responden yang berjenis kelamin perempuan hanya sebesar 42,6 persen. Hal ini 
menunjukkan bahwa responden laki-laki lebih banyak dibandingkan perempuan. Apabila dilihat dari usia responden mayoritas berusia 20-30 tahun yakni sebesar 39,4 persen, kemudian diikuti dengan kelompok usia 30-40 tahun sebesar 45,9 persen, kelompok usia 40-50 tahun sebesar 8,2 persen dan terakhir kelompok usia di atas 50 tahun sebesar 6,5 persen. Klasifikasi selanjutnya yakni klasifikasi pendidikan terakhir, dalam penelitian ini didominasi oleh pendidikan S1 yakni sebesar 50,8 persen, kemudian pendidikan D3 sebesar 31,1 persen, selanjutnya pendidikan tingkan SMA/SMK sebesar 14,8 persen, dan yang terakhir pendidikan S2 sebesar 3,3 persen.

Tabel 2.

Karakteristik Responden

\begin{tabular}{|c|c|c|c|c|}
\hline No. & Variabel & Klasifikasi & Jumlah (Orang) & Persentase (\%) \\
\hline \multirow[t]{4}{*}{1.} & Jenis & Laki - laki & 35 & 57,4 \\
\hline & Kelamin & Perempuan & 26 & 42,6 \\
\hline & & Jumlah & 61 & 100 \\
\hline & & $20-30$ & 24 & 39,4 \\
\hline \multirow[t]{6}{*}{2.} & Usia & $30-40$ & 28 & 45,9 \\
\hline & & $40-50$ & 5 & 8,2 \\
\hline & & Diatas 50 & 4 & 6,5 \\
\hline & & Jumlah & 61 & 100 \\
\hline & & SMA/SMK & 9 & 14,8 \\
\hline & Pendidikan & D3 & 19 & 31,1 \\
\hline \multirow[t]{2}{*}{3.} & Terakhir & $\mathrm{S} 1$ & 31 & 50,8 \\
\hline & & $\mathrm{S} 2$ & 2 & 3,3 \\
\hline \multirow{5}{*}{4.} & & Jumlah & 61 & 100 \\
\hline & Masa Kerja & $<1$ & 10 & 16,4 \\
\hline & & $1-3$ & 15 & 24,6 \\
\hline & & $>3$ & 36 & 59,0 \\
\hline & & Jumlah & 61 & 100 \\
\hline
\end{tabular}

Sumber : Data Primer Diolah, 2018

Klasifikasi berdasarkan masa kerja karyawan menunjukkan bahwa mayoritas responden memiliki masa kerja lebih dari 3 tahun dengan persentase 59,0 persen, kemudian responden dengan masa kerja selama 1-3 tahun dengan persentase 24,6 persen, dan terakhir kurang dari 1 tahun sebanyak 16,4 persen. 
Data yang ditunjukan Tabel 3 menampilkan proporsi jawaban responden, rata-rata jawaban, dan kriteria penilaian jawaban responden untuk masing-masing pernyataan pada variabel prestasi kerja karyawan.

\section{Tabel 3.}

Distribusi Jawaban Responden Terhadap Variabel Prestasi Kerja Karyawan

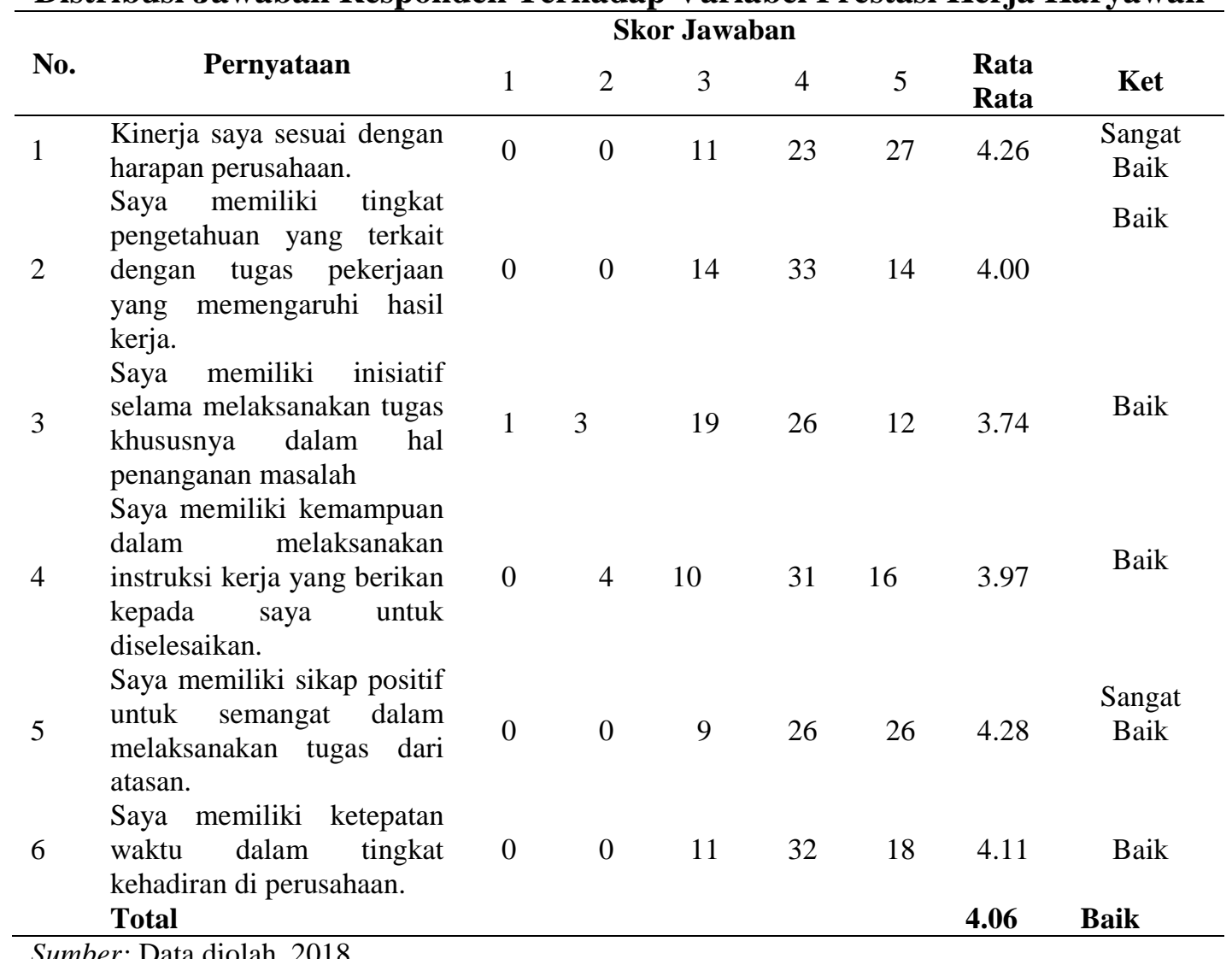

Tabel 3 menunjukan distribusi jawaban responden terhadap prestasi kerja karyawan dengan nilai rata-rata tertinggi sebesar 4,28 pada pernyataan saya memiliki sikap positif untuk semangat dalam melaksanakan tugas dari atasan dan untuk nilai rata-rata terendah sebesar 3,74 pada pernyataan "Saya memiliki inisiatif selama melaksanakan tugas khususnya dalam hal penanganan masalah". Nilai rata-rata untuk variabel prestasi kerja karyawan sebesar 4.06 termasuk dalam kriteria baik. 
Data yang ditunjukan Tabel 4 menampilkan proporsi jawaban responden, rata-rata jawaban, dan kriteria penilaian jawaban responden untuk masing-masing pernyataan pada variabel rekrutmen karyawan.

Tabel 4.

Distribusi Jawaban Responden Terhadap Variabel Rekrutmen Karyawan

\begin{tabular}{|c|c|c|c|c|c|c|c|c|}
\hline \multirow[b]{2}{*}{ No. } & \multirow[b]{2}{*}{ Pernyataan } & \multicolumn{5}{|c|}{ Skor Jawaban } & \multirow[b]{2}{*}{$\begin{array}{l}\text { Rata } \\
\text { Rata }\end{array}$} & \multirow[b]{2}{*}{ Ket } \\
\hline & & 1 & 2 & 3 & 4 & 5 & & \\
\hline 1 & $\begin{array}{l}\text { Saya ditawarkan gaji yang } \\
\text { menarik pada saat melamar } \\
\text { di perusahaan. } \\
\text { Saya sudah menerima }\end{array}$ & 0 & 0 & 18 & 27 & 16 & 3.97 & Baik \\
\hline 2 & $\begin{array}{ll}\text { kejelasan status saya sebagai } \\
\text { karyawan } & \text { tetap di } \\
\text { perusahaan } & \end{array}$ & 1 & 6 & 16 & 30 & 8 & 3.62 & Baik \\
\hline 3 & $\begin{array}{l}\text { Proses rekrutmen yang saya } \\
\text { ikuti pada perusahaan ini } \\
\text { telah sesuai dengan job } \\
\text { specification. }\end{array}$ & 0 & 4 & 20 & 25 & 12 & 3.74 & Baik \\
\hline 4 & $\begin{array}{l}\text { Setiap karyawan yang } \\
\text { bekerja disperusahaan ini } \\
\text { berikan kesempatan untuk } \\
\text { mengembangakan karirnya. }\end{array}$ & 0 & 1 & 17 & 28 & 15 & 3.93 & Baik \\
\hline 5 & $\begin{array}{l}\text { Rekrutmen yang dilakukan } \\
\text { perusahaan ini telah sesuai } \\
\text { dengan metode penarikan }\end{array}$ & 0 & 5 & 14 & 31 & 11 & 3.79 & Baik \\
\hline 6 & $\begin{array}{l}\text { Image perusahaan membuat } \\
\text { saya percaya dalam } \\
\text { mengambil keputusan untuk } \\
\text { memasukan lamaran di } \\
\text { perusahaan ini. }\end{array}$ & 0 & 2 & 15 & 29 & 15 & 3.93 & Baik \\
\hline & Total & & & & & & 3.83 & Baik \\
\hline
\end{tabular}

Sumber : Data diolah, 2018

Tabel 4 menunjukkan distribusi jawaban responden terhadap rekrutmen karyawan dengan nilai rata-rata tertinggi sebesar 3,97 pada pernyataan "Saya ditawarkan gaji yang menarik pada saat melamar di perusahaan" dan untuk nilai rata-rata terendah sebesar 3,62 pada pernyataan "Saya sudah menerima kejelasan status saya sebagai karyawan tetap di perusahaan”. Nilai rata-rata untuk variabel rekrutmen karyawan sebesar 3,83 termasuk dalam kriteria baik. 
Variabel seleksi karyawan diukur dengan menggunakan 5 pernyataan untuk menilai seleksi karyawan pada PT. Tunas Jaya Sanur. Data yang ditunjukan Tabel 5 menampilkan proporsi jawaban responden, rata-rata jawaban, dan kriteria penilaian jawaban responden untuk masing-masing pernyataan pada variabel seleksi karyawan.

Tabel 5.

Distribusi Jawaban Responden Terhadap Variabel Seleksi Karyawan

\begin{tabular}{|c|c|c|c|c|c|c|c|c|}
\hline \multirow{2}{*}{ No. } & \multirow{2}{*}{ Pernyataan } & \multicolumn{5}{|c|}{ Skor Jawaban } & \multirow{2}{*}{$\begin{array}{l}\text { Rata } \\
\text { Rata }\end{array}$} & \multirow{2}{*}{ Ket } \\
\hline & & 1 & 2 & 3 & 4 & 5 & & \\
\hline 1 & $\begin{array}{l}\text { Keahlian saya sesuai dengan } \\
\text { syarat yang dibutukan } \\
\text { perusahaan. }\end{array}$ & 0 & 1 & 16 & 20 & 24 & 4.10 & Baik \\
\hline 2 & $\begin{array}{l}\text { Pengalaman yang saya } \\
\text { miliki sesuai dengan } \\
\text { kualifikasi yang dibutukan } \\
\text { dalam seleksi karyawan }\end{array}$ & 0 & 2 & 20 & 28 & 11 & 3.79 & Baik \\
\hline 3 & $\begin{array}{l}\text { Kualifikasi pendidikan } \\
\text { menentukan seleksi } \\
\text { karyawan yang saya ikuti } \\
\text { Pada saat seleksi perusahaan }\end{array}$ & 0 & 7 & 16 & 18 & 20 & 3.84 & Baik \\
\hline 4 & $\begin{array}{l}\text { kerap menilai bakat setiap } \\
\text { calon karyawan. }\end{array}$ & 0 & 2 & 19 & 21 & 19 & 3.93 & Baik \\
\hline 5 & $\begin{array}{l}\text { Kesehatan fisik saya } \\
\text { memenuhi kualifikasi yang } \\
\text { ditetapkan perusahaan pada } \\
\text { saat seleksi karyawan. } \\
\text { Total }\end{array}$ & 0 & 1 & 9 & 23 & 28 & 4.28 & $\begin{array}{l}\text { Sangat } \\
\text { Baik }\end{array}$ \\
\hline
\end{tabular}

Sumber: Data diolah, 2018

Tabel 5 menunjukan distribusi jawaban responden terhadap seleksi karyawan dengan nilai rata-rata tertinggi sebesar 4.28 pada pernyataan "Kesehatan fisik saya memenuhi kualifikasi yang ditetapkan perusahaan pada saat seleksi karyawan." dan untuk nilai rata-rata terendah sebesar 3,79 pada pernyataan "Pengalaman yang saya miliki sesuai dengan kualifikasi yang dibutukan dalam seleksi karyawan". Jumlah nilai rata-rata untuk variabel selesi karyawan sebesar 3,99 termasuk dalam kriteria baik. 
Variabel pengembangan karir karyawan diukur dengan menggunakan 5 pernyataan untuk menilai pengembangan karir karyawan pada PT. Tunas Jaya Sanur. Data yang ditunjukan Tabel 6 menampilkan proporsi jawaban responden, rata-rata jawaban, dan kriteria penilaian jawaban responden untuk masing-masing pernyataan pada variabel pengembangan karir karyawan.

Tabel 6.

\section{Distribusi Jawaban Responden Terhadap Variabel Pengembangan Karir}

\begin{tabular}{|c|c|c|c|c|c|c|c|c|}
\hline \multirow{2}{*}{ No. } & \multirow{2}{*}{ Pernyataan } & \multicolumn{5}{|c|}{ Skor Jawaban } & \multirow{2}{*}{$\begin{array}{l}\text { Rata } \\
\text { Rata }\end{array}$} & \multirow{2}{*}{ Ket } \\
\hline & & 1 & 2 & 3 & 4 & 5 & & \\
\hline 1 & $\begin{array}{l}\text { Perusahaan memberikan } \\
\text { perlakuan yang adil pada } \\
\text { setiap karyawan dalam } \\
\text { pengembangan karir. }\end{array}$ & 0 & 2 & 17 & 29 & 13 & 3.87 & Baik \\
\hline 2 & $\begin{array}{l}\text { Atasan saya selalu } \\
\text { mendukung pengembangan } \\
\text { karir karyawannya. }\end{array}$ & 0 & 1 & 15 & 29 & 16 & 3.98 & Baik \\
\hline 3 & $\begin{array}{l}\text { Saya yakin berkompeten } \\
\text { dibidang pekerjaansaya } \\
\text { sekarang. }\end{array}$ & 0 & 3 & 15 & 23 & 19 & 3.90 & Baik \\
\hline 4 & $\begin{array}{l}\text { Saya merasa memiliki cukup } \\
\text { informasi mengenai promosi } \\
\text { jabatan yang ada di } \\
\text { perusahaan }\end{array}$ & 0 & 6 & 12 & 28 & 15 & 3.85 & Baik \\
\hline 5 & $\begin{array}{l}\text { Saya berminat untuk } \\
\text { dipromosikan atasan. }\end{array}$ & 0 & 1 & 12 & 22 & 26 & 4.20 & Baik \\
\hline & Total & & & & & & 3.96 & Baik \\
\hline
\end{tabular}

Sumber: Data diolah, 2018

Tabel 6 menunjukan distribusi jawaban responden terhadap retensi dengan nilai rata-rata tertinggi sebesar 4.20 pada pernyataan "saya berminat untuk dipromosikan atasan" dan untuk nilai rata-rata terendah sebesar 3,85 pada pernyataan "Saya merasa memiliki cukup informasi mengenai promosi jabatan yang ada di perusahaan". Nilai rata-rata untuk variabel pengembangan karir sebesar 3,96 termasuk dalam kriteria baik.

Sebelum analisis regresi dilakukan, data dalam penelitian ini diuji kelayakannya menggunakan uji asumsi klasik. Uji asumsi klasik dilakukan 
bertujuan untuk memastikan model dapat digunakan sebagai alat prediksi baik. Hasil uji asumsi klasik yang dilakukan dalam penelitian ini adalah uji normalitas, uji multikolinieritas dan uji heteroskedastisitas.

Uji normalitas bertujuan untuk menguji apakah dalam residual dari model regresi variable bebas dan variable terikat atau keduanya terdistribusikan secara normal atau tidak. Hasil uji normalitas dapat dilihat pada Tabel 7.

Tabel 7.

Hasil Uji Normalitas

\begin{tabular}{lc}
\hline & Unstandardized Residual \\
\hline $\mathrm{N}$ & 61 \\
Test Statistic & 0,506 \\
Kolmogorov-Smirnov $Z$ & \\
Asymp.Sig.(2-tailed) & 0,960 \\
\hline Sumber: Data Diolah, 2018 &
\end{tabular}

Berdasarkan Tabel 7 dapat dilihat bahwa nilai Test Statistic KolmogorovSmirnov sebesar 0,506 dan nilai Asymp.Sig sebesar 0,960 lebih besar dari 0,05 ini berarti residual dari persamaan regresi dalam penelitian ini terdistribusi secara normal. Nilai Kolmogorov-Smirnov merupakan koefisien yang digunakan untuk mengukur kenormalan distribusi data. Semakin besar nilai Kolmogorov-Smirnov maka semakin kecil nilai probabilitasnya (Asym.Sig) dan semakin besar nilai Kolmogorov-Smirnov maka semakin tidak normal distribusi data dalam suatu model uji.

Uji multikolinearitas bertujuan untuk menguji apakah pada model regresi ditemukan adanya korelasi antar variable bebas. Cara mendeteksi ada atau tidaknya korelasi antar sesama variabel bebas dapat dilihat dari nilai tolerance dan nilai variance inflation factor (VIF). Jika nilai tolerance lebih dari 10 persen $(0,1)$ 
VIF kurang dari 10, maka dikatakan tidak ada multikolinearitas. Hasil uji multikolinearitas antar variable bebas penelitian ini dapat dilihat pada tabel 8 .

Tabel 8.

Hasil Uji Multikolinearitas

\begin{tabular}{lccc}
\multicolumn{1}{c}{ Variabel } & Tolerance & VIF & Keterangan \\
\hline Rekrutmen $\left(\mathrm{X}_{1}\right)$ & 0,547 & 1,828 & Bebas Multikolinearitas \\
Seleksi Karyawan $\left(\mathrm{X}_{2}\right)$ & 0,695 & 1,439 & Bebas Multikolinearitas \\
Pengembangan Karir $\left(\mathrm{X}_{3}\right)$ & 0,516 & 1,937 & Bebas Multikolinearitas \\
\hline
\end{tabular}

Sumber: Data diolah, 2018

Tabel 8 menunjukkan bahwa masing-masing variable bebas memiliki nilai tolerance diatas 0,1 dan nilai variance factor (VIF) kurang dari 10, sehingga dapat dinyatakan bahwa tidak ada multikolinearitas antar variabel bebas. Hal ini berarti tidak ada kolerasi atau keterikatan antar variabel bebas yang diteliti.

Uji heterokedostisitas bertujuan untuk mengetahui apakah dalam model regresi terjadi ketidaksamaan varians dari residual satu pengamatan ke pengamatan lain yang dilakukan dengan uji Glejser. Jika tidak ada satu pun variable bebas yang berpengaruh signifikan terhadap nilai absolute residual atau nilai signifikansinya di atas 0,05 maka tidak mengandung gejala heteroskedastisitas. Hasil uji heteroskedastisitas variable bebas penelitian ini dapat dilihat pada Tabel 9.

Tabel 9.

Hasil Uji Heteroskedastisitas

\begin{tabular}{clccccc}
\hline \multirow{2}{*}{ Model } & & $\begin{array}{c}\text { Unstandardized } \\
\text { Coefficients } \\
\text { Std. } \\
\text { Error }\end{array}$ & $\begin{array}{c}\text { Standardized } \\
\text { Coefficients }\end{array}$ & Beta & Sig. \\
\hline 1 & (Constant) & 1.149 & 1.254 & - & .916 & .363 \\
2 & Rekrutmen & -.011 & .064 & -.031 & -.175 & .861 \\
3 & Seleksi & -.080 & .059 & -.209 & -1.352 & .182 \\
4 & Pengembangan Karir & .112 & 0.73 & .274 & 1.527 & .132 \\
\hline Sumber:
\end{tabular}

Sumber: Data diolah, 2018 
Berdasarkan Tabel 9 diatas dapat dilihat bahwa hampir semua variabel memiliki nilai sig > 0,05 ini berarti pada model regresi tidak terjadi gejala heteroskedasitisitas.

Analisis regresi linear berganda bertujuan untuk mengetahui ketergantungan suatu variabel terikat dengan satu atau lebih variabel bebas menurut Wirawan (2009). Analisis ini juga dapat menduga arah dari hubungan tersebut serta mengukur derajat keeratan hubungan antara satu variabel terikat dengan satu variabel bebas. Hasil analisis regresi dengan program statitical pacage of social science (SPSS) versi 16.0 for Windows dapat dilihat pada Tabel 10.

Tabel 10.

Rangkuman Hasil Analisis Regresi Linear Berganda

\begin{tabular}{lccccc}
\hline \multicolumn{1}{c}{ Model } & \multicolumn{2}{c}{$\begin{array}{c}\text { Unstandardized } \\
\text { Coefficients } \\
\text { B }\end{array}$} & $\begin{array}{c}\text { Standardized } \\
\text { Coefficients } \\
\text { Beta }\end{array}$ & T & Sig. \\
& B & & \\
\hline 1 (Constant) & 4.021 & 2.108 & - & 1.908 & 0,061 \\
Rekrutmen & 0,292 & 0,292 & 0,297 & 2.712 & 0,009 \\
Seleksi Karyawan & 0,358 & 0,358 & 0,349 & 3.588 & 0,00 \\
Pengembangan Karir & 0,328 & 0,328 & 0,300 & 2.656 & 1 \\
& & & & & 0,010 \\
R & & & & & 0,791 \\
R Square & & & & 0,625 \\
F Statistik & & & & & 31,681 \\
Sig. F & & & & & \\
\hline Sumber: Data diolah, 2018 & & & & &
\end{tabular}

Berdasarkan Tabel 10 dapat ditulis persamaan regresi linear berganda sebagai berikut:

$$
\mathrm{Y}=4.021+0,292 \mathrm{X}_{1}+0,358 \mathrm{X}_{2}+0,328 \mathrm{X}_{3}
$$

Dimana :

$\mathrm{Y} \quad=$ Prestasi Kerja Karyawan

$\mathrm{X}_{1} \quad=$ Rekrutmen

$\mathrm{X}_{2} \quad=$ Seleksi Karyawan

$\mathrm{X}_{3}=$ Pengembangan Karir

$\mathrm{R}^{2} \quad=$ Koefisien determinasi 
Berdasarkan persamaan hasil regresi linear berganda melalui uji SPSS, dapat dijelaskan bahwa nilai koefisien regresi rekrutmen $\left(X_{1}\right)$ sebesar 0,292 memiliki arti rekrutmen berpengaruh positif terhadap Prestasi kerja karyawan di PT. Tunas Jaya Sanur, apabila rekrutmen $\left(\mathrm{X}_{1}\right)$ meningkat maka prestasi kerja karyawan $(\mathrm{Y})$ akan mengalami peningkatan.

Nilai koefisien regresi seleksi karyawan $\left(\mathrm{X}_{2}\right)$ sebesar 0,358 memiliki arti bahwa seleksi karyawanberpengaruh positif terhadap Prestasi kerja karyawan di PT. Tunas Jaya Sanur, apabila seleksi karyawan $\left(\mathrm{X}_{2}\right)$ meningkat maka dari prestasi kerja karyawan (Y) akan mengalami peningkatan.

Nilai koefisien regresi pengembangan karir $\left(\mathrm{X}_{3}\right)$ sebesar 0,328 memiliki arti pengembangan karir memiliki pengaruh positif terhadap Prestasi kerja karyawan di PT. Tunas Jaya Sanur, apabila pengembangan karir $\left(\mathrm{X}_{3}\right)$ meningkat maka dari prestasi kerja karyawan (Y) akan mengalami peningkatan.

Uji Ketetapan Model (Uji F) bertujuan untuk menguji apakah model yang digunakan dalam penelitian ini layak atau tidak untuk digunakan sebagai alat analisis dalam menguji pengaruh variabel independen pada variabel dependennya. Adapun hasil dari pengujian kesesuaian model dalam penelitian ini telah disajikan pada Tabel 10 dapat dilihat bahwa nilai Sig. $F$ yakni 0,000 lebih kecil dari nilai $\alpha$ $=0,05$. Hal ini menunjukkan bahwa penelitian ini layak untuk digunakan sebagai alat analisisis untuk menguji pengaruh variabel independen pada variabel dependen.

Analisis Koefisien Determinasi digunakan untuk mengukur seberapa jauh kemampuan semua variabel bebas dalam menerangkan variasi dari variabel 
dependennya (Yuniarsih, 2008). Dalam penelitian ini koefisien determinasi dilihat melalui nilai $\mathrm{R}^{2}$. Adapun nilai dari $\mathrm{R}^{2}$ pada penelitian ini telah disajikan pada Tabel 10 dapat dilihat bahwa nilai dari $\mathrm{R}^{2}$ sebesar 0,625 dimana memiliki arti bahwa $62,5 \%$ variabel prestasi kerja dapat dijelaskan oleh variabel rekrutmen, slekesi, dan pengembangan karir. Sedangkan sisanya sebesar 37,5\% dipengaruhi oleh variabel lain diluar dari penelitian ini.

Hipotesis satu $\left(\mathrm{H}_{1}\right)$ dalam penelitian ini menyatakan bahwa rekrutmen karyawan berpengaruh positif terhadap prestasi kerja karyawan. Berdasarkan hasil pengujian pengaruh rekrutmen karyawan $\left(\mathrm{X}_{1}\right)$ pada prestasi kerja karyawan $(\mathrm{Y})$ yang ditunjukkan pada Tabel 10, diketahui bahwa tingkat signifikan sebesar 0,000 yang menunjukkan angka lebih kecil daripada taraf nyata dalam penelitian ini yaitu $\alpha=0,05$ dengan nilai koefisien regresi pengembangan karir sebesar 0,292. Hal ini menunjukkan bahwa rekrutmen karyawan berpengaruh positif pada prestasi kerja karyawan. Hasil ini menerima hipotesis $\mathrm{H}_{1}$ yakni rekrutmen karyawan berpengaruh positif terhadap prestasi kerja karyawan. Hasil penelitian ini sesuai dengan penelitian yang dilakukan oleh Rofaita (2012), Afriyie et al. (2013), Zulianti (2014), Lukiyana dan Sriyanto (2017) yang menunjukan rekrutmen karyawan berpengaruh positif dan signifikan terhadap prestasi kerja karyawan. Hal ini berart bahwa semakin bagus rekrutmen yang dilakukan oleh perusahaan maka prestasi kerja karyawan akan semakin meningkat.

Hipotesis dua $\left(\mathrm{H}_{2}\right)$ dalam penelitian ini menyatakan bahwa seleksi karyawan berpengaruh positif terhadap prestasi kerja karyawan. Berdasarkan hasil pengujian pengaruh seleksi karyawan $\left(\mathrm{X}_{2}\right)$ pada prestasi kerja karyawan (Y) yang 
ditunjukkan pada Tabel 10, diketahui bahwa tingkat signifikan sebesar 0,001 yang menunjukkan angka lebih kecil daripada taraf nyata dalam penelitian ini yaitu $\alpha=$ 0,05 dengan nilai koefisien regresi seleksi sebesar 0,358. Hal ini menunjukkan bahwa seleksi karyawan berpengaruh positif pada prestasi kerja karyawan. Hasil ini menerima hipotesis $\mathrm{H}_{2}$ yakni seleksi karyawan berpengaruh positif terhadap prestasi kerja karyawan. Hasil penelitian ini sesuai dengan penelitian yang dilakukan oleh Rofaita (2012), Omolo et al. (2012), dan Ekowoaba et al. (2015) yang menyatakan bahwa seleksi karyawan berpengaruh positif dan signifikan terhadap prestasi kerja karyawan. Hal ini mengindikasikan bahwa semakin baik penerapan seleksi karyawan maka prestasi kerja karyawan akan meningkat

Hipotesis tiga $\left(\mathrm{H}_{3}\right)$ dalam penelitian ini menyatakan bahwa pengembangan karir berpengaruh positif terhadap prestasi kerja karyawan. Berdasarkan hasil pengujian pengaruh pengembangan karir $\left(\mathrm{X}_{3}\right)$ pada prestasi kerja $(\mathrm{Y})$ yang ditunjukkan pada Tabel 10, diketahui bahwa tingkat signifikan sebesar 0,010 yang menunjukkan angka lebih kecil daripada taraf nyata dalam penelitian ini yaitu $\alpha=$ 0,05 dengan nilai koefisien regresi pengembangan karir sebesar 0,328 . Hal ini menunjukkan bahwa pengembangan karir berpengaruh positif terhadap prestasi kerja karyawan. Hasil ini menerima hipotesis $\mathrm{H}_{3}$ yakni pengembangan kari berpengaruh positif terhadap prestasi kerja karyawan. Hasil penelitian ini sesuai dengan penelitian yang dilakukan oleh Caroline et al. (2014), Wahyuni,dkk. (2014), Puspitasari dkk. (2015), Kawulusan dkk. (2016) yang menyatakan bahwa pengembangan karir berpengaruh positif dan signifikan terhadap prestasi kerja pegawai. Hal ini berarti bahwa semakin tinggi kesempatan pengembangan karir 
yang diberikan pada karyawan maka prestasi kerja yang dihasilkan karyawan akan semakin meningkat.

Berdasarkan hasil penelitian tersebut dapat dikemukakan implikasi secara teoritis dan praktis adalah faktor yang berhubungan dengan prestasi kerja karyawan dalam penelitian ini adalah rekrutmen, seleksi karyawan, dan pengembangan karir. Implikasi teoritis yang berkaitan dengan prestasi kerja karyawan secara konsisten memperkuat teori sebelumnya bahwa rekrutmen, seleksi karyawan, dan pengembangan karir mempengaruhi prestasi kerja karyawan. Dalam penelitian ini menyatakan bahwa rekrutmen karyawan memiliki pengaruh positif terhadap prestasi kerja karyawan, hal ini menunjukan bahwa semakin perusahaan menjalan sistem rekrutmen karyawan dengan tepat dan baik seperti melaksankan rekrutmen karyawan sesuai dengan metode penarikan karyawan pada PT Tunas Jaya Sanur maka akan semakin besar pengaruhnya pada karyawan untuk bisa berprestasi dalam pekerjaannya. Hasil penelitian berikutnya menyatakan bahwa seleksi karyawab berpengaruh positif terhadap prestasi kerja karyawan, hal ini menunjukan bahwa seleksi karyawan yang dilaksankan semakin baik sesuai dengan keahlian, pendidikan yang dimiliki oleh calon karyawan maka akan semakin besar pengaruhnya kepada karyawan yang akan diterima oleh perusahaan dan akan semangat dalam bekerja karena keahlian yang dimiliki akan dipergunakan dalam bekerja untuk itu akan dapat meningkat prestasi nya dalam bekerja. Hasil penelitian terakhir menyatakan bahwa pengembangan karir berpengaruh positif terhadap prestasi kerja jarywan, hal ini berarti semakin perusahaan melaksankan menjalankan pengembangan karir dengan tepat seperti 
memberikan kesempatan kepada seluruh karyawan dalam mengembangkan karirnya melalui program-program yang diberikan oleh PT Tunas Jaya Sanur maka akan semakin besar pengaruhnya pada karyawan untuk bisa meningkatkan prestasi kerjanya sehingga prestasi kerja karyawa akan tetap terjaga dan bahkan meningkat.

Hal ini mendukung penelitian yang telah diungkapkan pada hipotesis penelitian, sehingga dapat disimpulkan bahwa penelitian ini mendukung serta memperjelas hubungan antara variabel rekrutmen, seleksi, pengembangan karir, dan prestasi kerja karyawan.

Penelitian ini diharapkan akan memberikan kontribusi positif bagi semua pihak khususnya pegawai dan perusahaan. Bagi pegawai hendaknya ikut ambil bagian dan memiliki loyalitas tinggi untuk tetap menjaga dan meningkatkan prestasi kerja karyawan, karena merupakan suatu kepuasan tersendiri bagi pegawai jika mampu meningkatkan pengetahuan tentang pekerjaan yang diembannya dan mampu menunjukan bahwa semkin tinggi dapat meningkatkan prestasi kerjanya dalam perusahaan makan akan semakin tinggi pula kualitas kerja perusahaan. Bagi pihak perusahaan dalam menjaga dan meningkatkan prestasi kerja karyawan sebaiknya meperhatikan dalam melaksankan rektutmen karyawan, seleksi karyawan, dan pengembangan karir para karyawan agar dapat berjalan dengan baik dan sesuai dengan metode yang telah ditetapkan oleh perusahaan, hal ini penting karena aspek tersebut dapat mempengaruhi produktivitas dan kinerja PT Tunas Jaya Sanur. 


\section{SIMPULAN DAN SARAN}

Berdasarkan hasil dan pembahasan yang telah diuraikan pada bab sebelumnya, maka diperoleh simpulan bahwa Rekrutmen karyawan memiliki pengaruh positif terhadap prestasi kerja karyawan pada PT Tunas Jaya Sanur. Hal ini menunjukan bahwa semakin baik rekrutmen yang dilaksanakan oleh perusahaan maka akan semakin dapat meningkatkan prestasi karyawan dalam bekerja.

Seleksi karyawan memiliki pengaruh positif terhadap prestasi kerja karyawan pada PT Tunas Jaya Sanur. Hal ini menunjukan bahwa semakin baik pelaksanaan seleksi karyawan oleh perusahaan maka akan semakin banyak karyawan yang dapat menunjukan prestasinya dalam bekerja.

Pengembangan karir memiliki pengaruh positif terhadap prestasi kerja karyawan pada PT Tunas Jaya Sanur. Hal ini menunjukan bahwa semakin baik pelaksanaan pengembangan karir karyawan yang diberikan terhadap karyawan maka akan semakin dapat meningkatkan prestasi karyawan dalam bekerja.

Saran yang dapat diberikan, berdasarkan pada hasil analisis, pembahasan dan simpulan adalah pada variabel rekrutmen karyawan diperoleh rata-rata terendah pada pernyataan "saya sudah menerima kejelasan status sebagai karyawan tetap di perusahaan”, maka dari itu perusahaan diharapkan untuk memberikan kejelasan status bagi karyawan yang akan bekerja di perusahaan guna untuk memperjelas status bagi mereka dan rasa percaya untuk bekerja di perusahaan, dengan demikian mereka akan bekerja dengan rasa nyaman dan memberikan prestasi kerja yang baik. 
Variabel seleksi karyawan diperoleh rata-rata terendah pada pernyataan "saya memiliki pengalaman sesuai dnegan kualifikasi yang dibutuhkan dalam seleksi karyawan" maka dari itu perusahaan diharapkan untuk berhati-hati dalam melaksanakan proses slekesi karyawan. Perusahaan harus mengetahui pengalaman yang dimiliki oleh calon karyawan tersebut, dikarenakan pengalaman tersebut sangat mempengaruhi kinerjanya diperusahaan.

Variabel pengembangan karir diperoleh raya-rata terrendah pada pernyataan "saya merasa memiliki cukup informasi mengenai promosi jabatan yang ada di perusahaan" maka dari itu perusahaan sebaiknya memberikan informasi yang jelas mengnai promosi jabatan yang ada dalam perusahaan tersebut.

Variabel prestasi kerja karyawan diperoleh rata-rata terendah pada pernyataan "saya memiliki inisiatif selama melaksanakan tugas khususnya dalam hal penanganan masalah" maka dari itu perusahaan sebaiknya memberikan pengarahan kepada karyawan agar lebih semangat bekerja dan memberikan rasa nyaman pada karyawan yang bekerja diperusahaan, jika semangat bekerjadan rasa nyaman tersebut muncul maka karyawan akan bekerja dengan nyaman dan sepenuh hatinya.

\section{REFERENSI}

Abdul, Hameed. (2014). Impact Of Compensation on Performance (Empirical Evidence From Banking Sector Of Pakistan). Journal Of Business and Social Science. 5(2): 302-309.

Afriyie, Emelia Ohene and George Abaka Blankson. (2013). Effect Of Recruitmen And Selection Practices On The Performance Of Small and Medium Hotels Of Osu klottey Sub-Metropolitan Assembly Greater Accra. Journal Developing Country Studies. 3(11): 2224-6076. 
Akmal, Umar. (2015). The Effect Of Motivation and Career Development Against employess Performance and Job Statisfocation On The Governor office South Sulawesi Province, Indonesia. International Journal Of Management Science. 5(9): 628-638.

Ardana, I. K., Ni Wayan Mujiati., I Wayan Mudiartha Utama. (2012). Manajemen Sumber Daya Manusia. Yogyakarta: Graha Ilmu.

Basuki, Kustiadi. (2017). Pengaruh Pengembangan Karir Dan Motivasi Kerja Terhadap Prestasi Kerja Karyawan Dimediasi Kepuasan Kerja Pada PT. Master Wovenindo Jakarta Utara. Jurnal Universitas 17 Agustus 1945 Jakarta. 6(01): 2302-1769.

Cahyono, Eko Aprihadi dan I.G.A Dewi Adnyani. (2014). Pengaruh Gaya Kepemimpinan, Motivasi Kerja dan Iklim Organisasi Terhadap Prestasi Kerja Karyawan Bagian Engeneering Pada PT. Arabikatama Khatulistiwa Fishing Industry Denpasar. E-Jurnal Manajemen Unud. 3(9), hal. 2784-2798.

Caroline, Oduma and Susan, Were. (2014). Influence Of Career Development On Employee Perfomance In The Public University, A Case Of Kenyatta University. Journal of Social Sciences. 1(2): 1-16.

Charles, Akomes Bonsu and Anthany Kusi. (2014). Effect Of Career Development On Job Performance Of Local Government Workers In Ghana. International Journal Of Management Scienes. 2(8): 337-350.

Chukwudi, Francis Anyim. (2014). Recruitmen and Employees Performance In The Public And Private Sector In Nigeria. International Journal Of Business Administrasion. 3(1): 31-40.

Dini, Krismasari., dan Agus Frianto. (2014). Pengaruh Kompensasi dan Disiplin Kerja Terhadap Prestasi Kerja Karyawan Pabrik Gula Tjoekir. Jurnal Ilmu Manajemen. 2(4): 1584-1592.

Ekowoaba, Joy. O., Ugochukw. V. I., and Ndubuisi. V. (2015). The Impact Of Recruitmen And Celection Criteria On Organizational Performance. Global International Journal Of Human Resources Management. 3(2): 2053-5694.

Hasibuan, Melayu S.P (2007). Manajemen Sumber Daya Manusia. Jakarta : Cetakan PT Bumi Aksara.

Heikal, M. (2016). Pengaruh Stres Kerja Dan Pengembangan Karir Terhadap Prestasi Kerja Karyawan Pada PT. Jasa Marga (Persero) Tbk Cabang Belmera. Jurnal Administrasi Bisnis. 17(01), hal. 27-42.

Irfan W. (2012) Pengaruh Pelaksanaan Seleksi Terhadap Prestasi Kerja Karyawan Pada Kantor Pusat PDAM Kota Semarang. Jurnal Ilmu Administrasi Bisnis. 2(3), hal. 192-198. 
Kawulusan, A.A., J. Sepang., dan C. Mintardjo. (2016). Pengaruh Pengmbangan Karir,Kompensasi dan Semangat Kerja Terhadap Prestasi Kerja Karyawan Pada PT. Pegadaian (Persero) Kanwil V Manado. Jurnal Berkala Ilmiah Efisiensi. 16(03): 1-9.

Kiruja, Elegwa Mukuru. (2013). Effect Of Selection On Employee Performance In Public Middle Level Technical Training Instutions In Kenya. Jurnal Of Advences In Management And economic. 2(4): 73-82

Kwenin, Daisy Ofosuhene. (2014). Relationship Between Work Environment, Career Development Opportunities and Employe Retention In Vodafone Ghana Limited. Global Journal Of Human Resources Management. 1(4): $1-9$.

Lukiyana dan Sriyanto. (2017). Pengaruh Rekrutmen dan Pengalaman Kerja Terhadap Prestasi Kerja Karyawan Dengan Penempatam Kerja Sebagai Variabel Intervening. Jurnal Online Internasional \& Nasional Universitas 17 Agustus 1945 Jakarta. 4(1): 2356-0304.

Masud, Ibrahim and Verinica, A.B. (2015). Impact Of Motivation On Employee Performance The Case Of Some Selected Micro Finance Companis In Ghana. International Joirnal Of Economics, Commerce and Management. 3(11): 1218-1236.

Nasution, Fauziah Namni., Emmy Mariatin., and Siti, Z. (2018) The Influence Of Career Development And Organizational Culture On Employe Performance. Internatioanl Journal of Scientific Research And Management. 6(1): 2321-3418.

Oaya, Zirra Clifford., Ogbu, J.O., and Ojo, G.R. (2017). Impact Of Recruitment And Selection Strategy On Employees Performance : a study Of Three Selected Manufakturing Companies In Nigeria. Internatioanl Journal of Innovation And Economic Development. 3(3): 1849-7020

Omolo, Jonathan.W., Moses, N.O., and Wilis, Y.O. (2012). Effect Of Recruitmen And Selection Of Employees On The Performance Of Small And Medium Enterprises In Kisumu Municipality, Kenya. Journal Of Human Resurce Studies. 2(3): 2162-3058.

Puspitasari, Tenny. (2015). Pengaruh Pengembangan, Penempatan Jabatan Dan Motivasi Terhadap Prestasi Kerja Pegawai. Jurnal Sains Manajemen Universitas Palangka Raya. 4(01): 2302-1411.

Richard, George V. (2004). International Best Practices In Carrer Development : Review Of The Literature. Association of American Medical Collages. 6(18): 212-215.

Rivai, V. (2008). Manajemen Sumber Daya Manusia untuk Perusahaan. Edisi Pertama. Jakarta; PT. Raja Grafindo Persada 
Rofaita, W. (2012). Analisis Rekrutmen Dan Seleksi Terhadap Prestasi Kerja Karyawan Pada CV. Waeasulla Pekanbaru. Jurnal Administrasi Bisnis. 4(4): 6-9.

Rofiatun, Siti., Yulianeu., Fathoni, A., dan Malik, D. (2017). Pengaruh Rekrutmen, Pengembangan Karir Dan Penempatan Terhadap Prestasi Kerja Kryawan Bagian Produksi Di PT. Sai Garments Industries Semarang. Jurnal Universitas Pandanaran Semarang. 4(11), hal. 1-20.

Sari dan Sinulingga. (2011). Manajemen Pengembangan Karir Karyawan. Edisi Pertama. Bandung: Salemba Empat.

Sarinah, Rahmat, S.G., dan Asep, A.T. (2016). The Effec Of Recrutmen And Employee Selection On Employee Placement And Its Impacts Towards Employee Performance At PT. Sriwijaya Air. Jurnal Manajemen Transportasi \& Logistik. 3(1): 1355-4724.

Siagian, P, S. (2012). Manajemen Sumber Daya Manusia. Jakarta.Bumi Aksara.

Simamora, Henry. 2006. Manajemen Sumber Daya Manusia. Yogyakarta: Bagian Penerbitan Sekolah Tinggi Ilmu Ekonomi YKPN.

Sunday, Adeyemi. O., Dumade, E.O., and Fadre, O.M. (2015). The Influence Of Recruitmen And Selection On Organizational Performance. International Journal Of Advanced Academic Research-Social At Sciences And Edication. 5(6): 1-63

Taghulihi, Iin Agelia. (2015). The Effect Of Motivation, Career Development, And Discipline On Employee Performance At PT. Bank Sulutgo In Tagulandang. International Journal Business Administration Program. 15(5): 3211-4551.

Wahyuni, Dwi, Hamidah.N.K., dan Ika Ruhana. (2014). Pengaruh Pengembangan Karir Terhadap Prestasi Kerja Karyawan Pada PT. Astra Internasional, Tbk Daihatsu Malang. Jurnal Administrasi Binsis. 8(1): 4-9

Wirawan. (2009). Evaluasi Kinerja Sumber Daya Manusia: Teori Aplikasi dan Penelitian. Jakarta: Salemba Empat.

Yuniarsih, T. (2008). Teori, Apliskasi, dan Isu Penelitian: Manajemen Sumber Daya Manusia. Bandung: Alfabeta.

Zulianti. (2014). Pengaruh Strategi Rekrutmen, Seleksi dan Penempatan Pegawai Terhadap Prestasi Kerja Pegawai Di Lingkungan Pemerintah Kota Semarang. Jurnal Administrasi Bisnis. 8(2): 1-9. 